\title{
T cells regulation modulated by Sambucus javanica extracts in DMBA-exposed mice
}

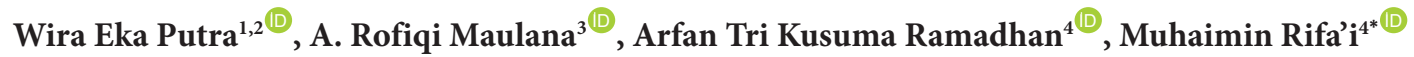 \\ ${ }^{1}$ Department of Biology, Faculty of Mathematics and Natural Sciences, Universitas Negeri Malang, Indonesia \\ ${ }^{2}$ Department of Biotechnology, Faculty of Mathematics and Natural Sciences, Universitas Negeri Malang, Indonesia \\ ${ }^{3}$ Department of Statistics, Faculty of Mathematics and Natural Sciences, Brawijaya University, Indonesia \\ ${ }^{4}$ Department of Biology, Faculty of Mathematics and Natural Sciences, Brawijaya University, Indonesia
}

\section{A R T I C L E I N F O}

Article Type:

Original Article

\section{Article History:}

Received: 1 September 2018

Accepted: 17 May 2019

\section{Keywords:}

DMBA

Naive T cells

Regulatory T cells

S. javanica

\begin{abstract}
A B S T R A C T
Introduction: Sambucus is a genus of the Adoxaceae family and has been widely used as a food and medicinal source. In this study, we aimed to evaluate the effects of $S$. javanica extracts toward $\mathrm{T}$ cells regulation in the 7,12-dimethylbenzene (a) anthracene (DMBA)-exposed mice.

Methods: Thirty mice were used in this experiment which divided into six treatment groups and five times repetition. Three-month-old BALB/c mice were administrated with $2.8 \mathrm{mg} \cdot \mathrm{kg}^{-1} \mathrm{BW}$ of DMBA as carcinogen agent for ten times within four weeks, then continuously treated with 400 and $800 \mathrm{mg} \cdot \mathrm{kg}^{-1} \mathrm{BW}$ of $S$. javanica berries leaves extracts daily for two weeks. Treatment groups in this study were vehicle as negative control, DMBA $2.8 \mathrm{mg} \cdot \mathrm{kg}^{-1} \mathrm{BW}$ as positive control; BD1 group, DMBA $2.8 \mathrm{mg} \cdot \mathrm{kg}^{-1}+$ berries extracts $400 \mathrm{mg} \cdot \mathrm{kg}^{-1} \mathrm{BW}$; BD2 group, DMBA $2.8 \mathrm{mg} \cdot \mathrm{kg}^{-1}$ + berries extracts 800 mg.kg ${ }^{-1}$ BW; LD1 group, DMBA 2.8 mg.kg-1 + leaves extract $400 \mathrm{mg} \cdot \mathrm{kg}^{1} \mathrm{BW}$; and LD2 group, DMBA $2.8 \mathrm{mg} \cdot \mathrm{kg}^{-1}+$ leaves extract $800 \mathrm{mg} \cdot \mathrm{kg}^{-1}$ BW. The relative number of CD4 $4^{+} \mathrm{CD} 25^{+} \mathrm{CD} 62 \mathrm{~L}^{+}$ cells and $\mathrm{CD} 4^{+} \mathrm{CD} 62 \mathrm{~L}^{+}$cells were measured and analyzed by using flow cytometer.

Results: DMBA induction decreased the relative number of $\mathrm{CD} 4{ }^{+} \mathrm{CD} 25^{+} \mathrm{CD} 62 \mathrm{~L}^{+}$cells while the leaves extract of $S$. javanica significantly increased their expression. Furthermore, DMBA promoted the relative number of $\mathrm{CD} 4^{+} \mathrm{CD} 62 \mathrm{~L}^{+}$cells expression while leaves and berries extracts of $S$. javanica sharply suppressed its expression.

Conclusion: The results suggest that, $S$. javanica extracts may exert their medicinal properties by modulating T cells regulation in DMBA-induced mice.
\end{abstract}

Implication for health policy/practice/research/medical education:

Berries and leaves extracts of Sambucus javanica modulated the $\mathrm{T}$ cells regulation by increasing the relative number of $\mathrm{CD} 4{ }^{+} \mathrm{CD} 25^{+} \mathrm{CD} 62 \mathrm{~L}^{+}$regulatory $\mathrm{T}$ cells and decreasing the relative $\mathrm{CD} 4{ }^{+} \mathrm{CD} 62 \mathrm{~L}^{+}$cells after exposed by DMBA. These results suggest that Sambucus javanica has therapeutical potential against the unfavorable effects of DMBA by modulating the T cells regulation.

Please cite this paper as: Putra WE, Maulana AR, Ramadhan ATK, Rifa'i M. T cells regulation modulated by Sambucus javanica extracts in DMBA-exposed mice. J Herbmed Pharmacol. 2020;9(4):408-411. doi: 10.34172/jhp.2020.51.

\section{Introduction}

DMBA (7,12-dimethylbenzene (a) anthracene) is a part of polycyclic aromatic hydrocarbons family known as a carcinogenic pollutant abundantly distributed in the environment $(1,2)$. As a carcinogenic agent, DMBA is profoundly utilized as a tumor initiator in experimental animals (3-5). Chemicals exposed like DMBA positively affect the biological system into the adverse condition. A study conducted by Paliwal et al stated that numerous adverse effects of DMBA's toxicity might affect on a broad range of biological systems such as excretion, immune, and transportation systems. Therefore, the strategy to reduce the unwanted impacts of DMBA's toxicity is highly needed (6).

Recently, traditional medicines have been reached their popularity in primary health care. Affordable, less harmful side effects and cost-effectiveness might be the more significant reasons for utilizing traditional medication (7). For a long time, several ethnic groups have already used Sambucus as a food and medicinal source (8). Sambucus is a group of herbs widely known for its therapeutic potencies as an anti-inflammatory, anti-oxidant, antidiabetes remedy, and hematopoiesis promoting agent (912). In the present study, we systematically evaluated the 
effects of leaves and berries extracts of S. javanica toward $\mathrm{T}$ cells regulation in DMBA-exposed mice.

\section{Materials and Methods}

Materials Preparation

Plant materials were obtained from Materia Medica Batu, The Ministry of Health Indonesia. Ethanolic extraction was performed for both leaves and berries of S. javanica. In this study, the treatment doses of each extract were 400 and $800 \mathrm{mg} \cdot \mathrm{kg}^{-1} \mathrm{BW}$. The S. javanica extracts were stored at $-20^{\circ} \mathrm{C}$ refrigerator for further purposes.

\section{Experimental Treatments}

Thirty free pathogen $\mathrm{BALB} / \mathrm{c}$ mice were purchased from Animal Laboratory, Gadjah Mada University. Experimental mice then maintained in the animal facility, Department of Biology, Brawijaya University, Indonesia. In this study, the mice were administrated by $2.8 \mathrm{mg} \cdot \mathrm{kg}^{-1}$ BW DMBA (Tokyo Chemical Industry Co. Ltd.) for ten times in a month, then followed by 400 and 800 mg.kg-1 BW of S. javanica extracts treatment every day for two weeks. Treatment groups in this study were vehicle as negative control, DMBA $2.8 \mathrm{mg} \cdot \mathrm{kg}^{-1} \mathrm{BW}$ as positive control; BD1 group, DMBA $2.8 \mathrm{mg} \cdot \mathrm{kg}^{-1}+$ berries extract $400 \mathrm{mg} \cdot \mathrm{kg}^{-1} \mathrm{BW}$; BD2 group, DMBA $2.8 \mathrm{mg} \cdot \mathrm{kg}^{-1}+$ berries extract $800 \mathrm{mg} \cdot \mathrm{kg}^{-1} \mathrm{BW}$; LD1 group, DMBA $2.8 \mathrm{mg} \cdot \mathrm{kg}^{-1}$ + leaves extract $400 \mathrm{mg} \cdot \mathrm{kg}^{-1} \mathrm{BW}$; and LD2 group, DMBA $2.8 \mathrm{mg} \cdot \mathrm{kg}^{-1}+$ leaves extract $800 \mathrm{mg} \cdot \mathrm{kg}^{-1}$ BW. All contents of this study were confirmed by the Research Ethics Committee, Brawijaya University.

\section{Flow cytometry analysis}

The flow cytometry procedure in this study was similar to our previous research $(13,14)$. Splenocytes from each treatment group were stained by several antibodies including mouse anti-CD4, mouse anti-CD25, mouse anti-CD62L antibody (Biolegend). FACS Calibur ${ }^{\mathrm{TM}}$ flow cytometer (BD-Biosciences, San Jose, CA) and BD CellQuest Pro $^{\mathrm{TM}}$ software were used in this study.

\section{Statistical analysis}

Data analysis was done by student $t$-test with a significance level ( $\alpha$ ) of 0.05 . The data used in this study was based on a calculation of the relative number of $\mathrm{CD} 4^{+} \mathrm{CD} 25^{+} \mathrm{CD} 62 \mathrm{~L}^{+}$ regulatory $\mathrm{T}$ cells and $\mathrm{CD} 4^{+} \mathrm{CD} 62 \mathrm{~L}^{+}$naive $\mathrm{T}$ cells.

\section{Results}

Regulatory T cells population after $S$. javanica treatment As stated in the above explanation, BALB/c mice were treated by $S$. javanica extracts after exposed by DMBA. In the present study, we evaluated the regulatory $\mathrm{T}$ cells and naive $\mathrm{T}$ cells population by flow cytometer (Figure 1). According to the results, DMBA induction significantly suppressed the relative number of $\mathrm{CD} 4{ }^{+} \mathrm{CD} 25^{+} \mathrm{CD} 62 \mathrm{~L}^{+}$, regulatory $\mathrm{T}$ cells. Interestingly, the relative number of

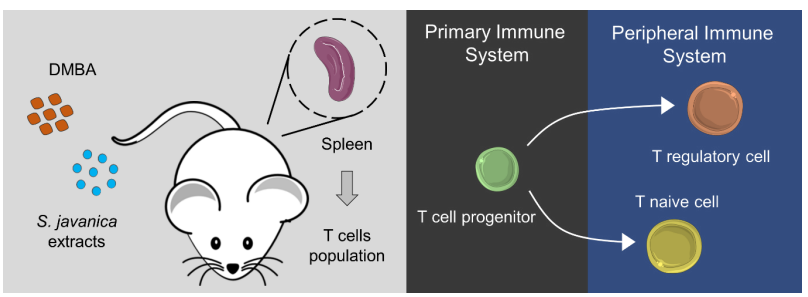

Figure 1. Schematic diagram about experimental treatments in this study. DMBA was occupied as carcinogenic agent, however S. javanica extracts could ameliorate the adverse effects of DMBA by modulating the T cells population.

regulatory $\mathrm{T}$ cells was promoted with the leaves extract with a dose of $800 \mathrm{mg} \cdot \mathrm{kg}^{-1} \mathrm{BW}$ (Figure 2).

Naive T cells population after S. javanica treatment To greater extends, we have evaluated and analyzed the relative number of $\mathrm{CD}^{+} \mathrm{CD} 2 \mathrm{~L}^{+}$naive $\mathrm{T}$ cells. In this study, we found that the relative number of naive $\mathrm{T}$ cells was contradicted with regulatory $\mathrm{T}$ cells. The results demonstrated the increasing number of $\mathrm{CD} 4^{+} \mathrm{CD} 62 \mathrm{~L}^{+}$ naive $\mathrm{T}$ cells after DMBA induction, however it was sharply decreased after treated by leaves and berries extracts of S. javanica (Figure 2).

\section{Discussion}

$\mathrm{T}$ cells have critical roles in the immune system as fine defender against microorganism infections and other foreign invaders. $\mathrm{T}$ cells were originated from bone marrow as the progenitor. During its development, T cells underwent the selection and maturation in the thymus before it becomes functional T cells $(15,16)$. After leaving the thymus, another subset of $\mathrm{T}$ cell population migrates into the secondary lymphoid organs via blood stream and lymph. Specifically, the migrated cells which carry particular markers such as CD62L and CCR7 are called naive $\mathrm{T}$ cells (17). Another subset of T cells with a specific function in self-tolerance respond and immunosuppressive properties is known as regulatory $\mathrm{T}$ cells $(18,19)$. More details, numerous studies have suggested that regulatory $\mathrm{T}$ cells are divided into two types, natural and inducible regulatory $\mathrm{T}$ cells which are originated from naive $\mathrm{T}$ cells in the periphery immune system (20). Unlike naive $\mathrm{T}$ cell, regulatory $\mathrm{T}$ cells are identified by the appearance of FOXp3 in $\mathrm{CD}^{+} \mathrm{CD} 25^{+} \mathrm{T}$ cell subset $(19,21)$.

Regarding the above results, we found the crucial role of $S$. javanica in T cells regulation of DMBA-exposed mice. It has been clearly demonstrated that the leaves extract of $S$. javanica contribute to modulating regulatory $\mathrm{T}$ cells population. On the other hand, the relative number of naive $\mathrm{T}$ cells is down-regulated toward leaves and berries extracts of $S$. javanica (Figure 2). These findings suggested that $\mathrm{T}$ cells regulation were altered by bioactive compounds of S. javanica after DMBA administration.

DMBA can induce oxidative damage during metabolic 

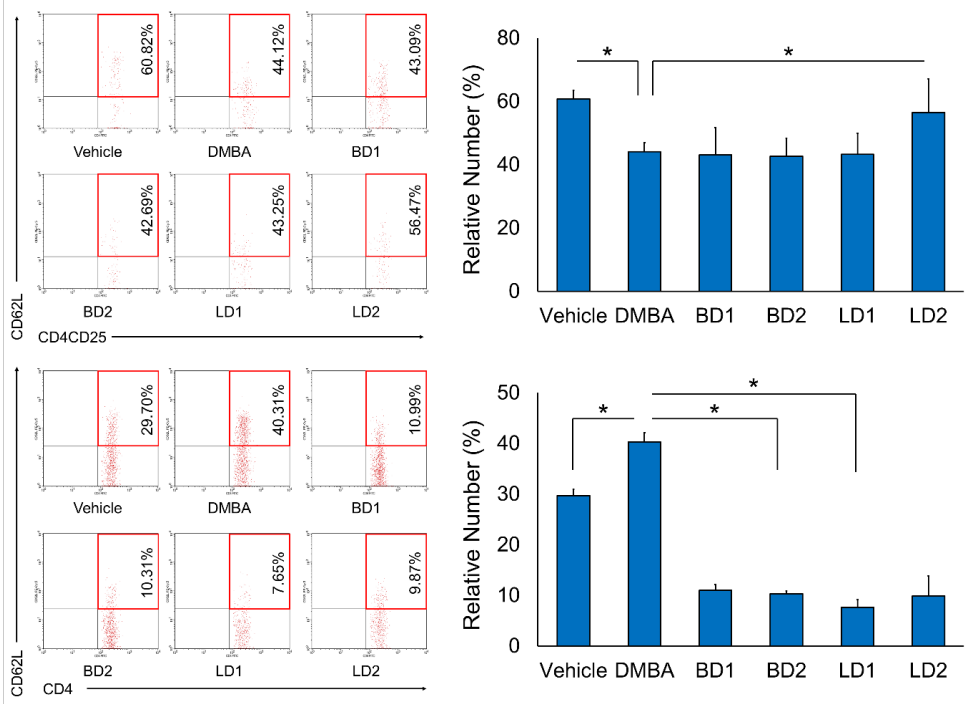

Figure 2. Effect of the leaves extract of $S$. javanica on the number of $C D 4^{+} C D 25^{+} C D 62 L^{+}$regulatory $T$ cells after down regulation by DMBA treatment. The number of $\mathrm{CD}^{+}{ }^{+} \mathrm{CD} 62 \mathrm{~L}^{+}$naïve $\mathrm{T}$ cells decreased by $\mathrm{S}$. javanica extracts. The bars are calculation of the relative number of $\mathrm{CD}^{+} \mathrm{CD} 25^{+} \mathrm{CD} 62 \mathrm{~L}^{+}$and $\mathrm{CD}^{+}{ }^{+} \mathrm{CD} 62 \mathrm{~L}^{+}$cells expression, respectively. The results in this study were represented as the mean $\pm \mathrm{SD}$. ${ }^{*} \mathrm{P}<0.05$. Treatment groups in this study were vehicle, DMBA $2.8 \mathrm{mg} \cdot \mathrm{kg}^{-1} \mathrm{BW}$;BD1, DMBA $2.8 \mathrm{mg} \cdot \mathrm{kg}^{-1}+$ berries extract $400 \mathrm{mg} \cdot \mathrm{kg}^{-1} \mathrm{BW}$;BD2, DMBA $2.8 \mathrm{mg}^{\mathrm{kg}}{ }^{-1}+$ berries extract $800 \mathrm{mg} \cdot \mathrm{kg}^{-1} \mathrm{BW}$;LD1, DMBA $2.8 \mathrm{mg} \cdot \mathrm{kg}^{-1}+$ leaves extract $400 \mathrm{mg} \cdot \mathrm{kg}^{-1} \mathrm{BW}$; and LD2, DMBA $2.8 \mathrm{mg} \cdot \mathrm{kg}^{-1}+$ leaves extract $800 \mathrm{mg} \cdot \mathrm{kg}^{-1} \mathrm{BW}$.

activation by promoting the production of reactive oxygen species such as superoxide anion, hydrogen peroxidase, and hydroxyl radical (22). A study conducted by Manoharan and Selvan revealed that geraniol could exert the protective effect against tumor formation in DMBA exposed mice by modulating the activities of free radical scavenging (23). Similarly, the extract of Syzygium cumini seed and Aloe vera also showed the ameliorative effect toward adverse alteration of DMBA in Swiss albino mice $(24,25)$. The successive methanol extract of Ficus benghalensis has been known to have immunostimulant activity in lymphocyte proliferation such as T cells and B cells (26). Another in vivo experiment in tumor-bearing mice proved the methanol extract of Nitraria retusa leaves significantly promoted splenocyte proliferation and boosted the activity of natural killer cells and cytotoxic T lymphocytes (27). Similarly, in vitro and in vivo experiments revealed that Mesembryanthemum crystallinum extract was able to enhance human B and $\mathrm{T}$ cell lines proliferation (28).

\section{Conclusion}

In this study, DMBA induction suppressed the relative number of $\mathrm{CD} 4{ }^{+} \mathrm{CD} 25^{+} \mathrm{CD} 62 \mathrm{~L}^{+}$regulatory $\mathrm{T}$ cells while the leaves extract of $S$. javanica significantly promoted their expression. Oppositely, in the case of naive $\mathrm{T}$ cells, DMBA enhanced the relative number of $\mathrm{CD} 4{ }^{+} \mathrm{CD} 62 \mathrm{~L}^{+}$ cells expression while leaves and berries extracts of $S$. javanica precipitously decreased its expression.

\section{Acknowledgement}

Authors acknowledge the members of Animal Anatomy and Physiology Laboratory, Department of Biology, Brawijaya University for valuable assistance in this study.

\section{Authors' contributions}

WEP performed the experiment, analysis, and wrote the manuscript. ARM and ATKR performed the experiment. MR designed the experiment and revised the manuscript. All authors approved the final version of this manuscript for publication.

\section{Conflict of interests}

No conflict of interest.

\section{Ethical considerations}

All aspects of ethical issues have been observed by the authors. These experimental studies were approved by the ethical committee of Brawijaya University, Malang, Indonesia with ethical clearance no. 312-KEP-UB and were conducted adhering to the National Institutes of Health Guide for the Care and Use of Laboratory Animals (1978).

\section{Funding/Support}

None.

\section{References}

1. Dakrory AI, Fahmy SR, Soliman AM, Mohamed AS, Amer SAM. Protective and curative effects of the sea cucumber Holothuria atra extract against DMBA-induced hepatorenal diseases in rats. Biomed Res Int. 2015;2015:1-11. Doi: $10.1155 / 2015 / 563652$.

2. Saha D, Hait M. An ontological design: two stage mouse skin carcinogenesis induced by DMBA and promoted by 
croton oil. Asian J Res Pharm Sci. 2012;2(1):1-3.

3. Vishnoi S, Agarwal RC. Chemopreventive action of Bacopa monnieri (Brahmi) hydromethanolic extract on DMBA-induced skin carcinogenesis in Swiss albino mice. J Pharmacogn Phytochem. 2013;2(2):197-202.

4. Thakur P, Sanyal SN. Chemopreventive role of preferential COX-2 inhibitor diclofenac in 9, 10-dimethybenz(a) anthracene induced experimental lung carcinogenesis. Am J Biomed Sci. 2010;2(3):275-288. doi: 10.1016/j.yexmp. 2010.03.005.

5. Sancheti G, Goyal PK. Effect of Rosmarinus officinalis on DMBA-induced mouse skin tumorigenesis: a preliminary study. Pharmacologyonline. 2007;1:545-556.

6. Paliwal R, Sharma V, Pracheta, Sharma S, Yadav S, Sharma S. Anti-nephrotoxic effect of administration of Moringa oleifera Lam in amelioration of DMBA-induced renal carcinogenesis in Swiss albino mice. Biol Med. 2011;3(2):2735.

7. Wachtel-Galor S, Benzie IFF. Herbal medicine: an introduction to its history, usage, regulation, current trends, and research needs. In: Benzie IFF, Wachtel-Galor S, editors. Herbal Medicine: Biomolecular and Clinical Aspects. 2nd ed. Boca Raton (FL): CRC Press/Taylor \& Francis; 2011.

8. Charlebois D, Byers PL, Finn CE, Thomas AI. Elderberry: Botany, horticulture, potential. In: Janick J, ed. Horticultural Reviews. Oxford: Wiley-Blackwell; 2010.

9. Ebrahimzadeh MA, Enayatifard R, Khalili M, Ghaffarloo M, Saeedi M, Yazdani Charati J. Correlation between sun protection factor and antioxidant activity, phenol and flavonoid contents of some medicinal plants. Iran J Pharm Res. 2014;13:1041-7.

10. Putra WE, Rifa'i M. Hematopoiesis activity of Sambucus javanica on chloramphenicol-induced aplastic anemia mouse model. Nat Prod Sci. 2019. 25(1):59-63. doi: 10.20307/nps.2019.25.1.59.

11. Sidor A, Gramza-Michałowska A. Advanced research on the antioxidant and health benefit of elderberry (Sambucus nigra) in food-A review. J Funct Foods. 2014;18:941-958. doi: 10.1016/j.jff.2014.07.012.

12. Kiselova $Y$, Ivanova D, Chervenkov T, Gerova D, Galunska $\mathrm{B}$, Yankova T. Correlation between the in vitro antioxidant activity and polyphenol content of aqueous extracts from Bulgarian herbs. Phytother Res. 2006;20:961-5. doi: 10.1002/ptr.1985.

13. Putra WE, Soewondo A, Rifa'i M. Effect of dexamethasone administration toward hematopoietic stem cells and blood progenitor cells expression on $\mathrm{BALB} / \mathrm{c}$ mice. J. Pure App Chem Res. 2015;4(3):100-8. doi: 10.21776/ ub.jpacr.2015.004.03.221

14. Putra WE, Soewondo A, Rifa'i M. Expression of erythroid progenitor cells and erythrocytes on dexamethasone induced-mice. J Biotropika. 2015;3(1):42-45.

15. Koch U, Radtke F. Mechanisms of T cell development and transformation. Annu Rev Cell Dev Biol. 2011;27:539-562. doi: 10.1146/annurev-cellbio-092910-154008.
16. Sakaguchi S, Powrie F. Emerging challenges in regulatory T cell function and biology. Science. 2007;317(5838):627-9. doi: 10.1126/science.1142331.

17. Berard M, Tough DF. Qualitative differences between naïve and memory T cells. Immunology. 2002;106(2):127-38. doi: 10.1046/j.1365-2567.2002.01447.x.

18. Putra WE, Waffareta E, Ardiana O, Januarisasi ID, Soewondo A, Rifa'i M. Dexamethasone-administrated $\mathrm{BALB} / \mathrm{c}$ mouse promotes proinflammatory cytokine expression and reduces $\mathrm{CD} 4+\mathrm{CD} 25+$ regulatory $\mathrm{T}$ cells population. Bioscience Research. 2017;14(2):201-213.

19. Fritzsching B, Oberle N, Pauly E, Geffers R, Buer J, Poschl J, et al. Naive regulatory T cells: A novel subpopulation defined by resistance toward CD95L-mediated cell death. Blood. 2006;108(10):3371-8. doi: 10.1182/blood-2006-02-005660.

20. Burrell BE, Nakayama Y, Xu J, Brinkman CC, Bromberg JS. Treg induction, migration, and function in transplantation. J Immunol. 2012;189(10):4705-11. doi: 10.4049/ jimmunol.1202027.

21. Safinia N, Scotta C, Vaikunthanathan T, Lechler RI, Lombardi G. Regulatory T cells: Serious contenders in the promise for immunological tolerance in transplantation. Front Immunol. 2015;6:438. doi: 10.3389/ fimmu.2015.00438.

22. Rengarajan $\mathrm{T}$, Jagadeesan AJ, Balamurugan A, Balasubramanian MP. Chemotherapeutic potential of D-Pinitol against 7, 12 dimethylbenz (a) anthracene (DMBA) induced mammary carcinoma in Sprague Dawley rats. Int J Pharma Bio Sci. 2011;2(4):232-41.

23. Manoharan S, Selvan MV. Chemopreventive potential of geraniol in 7,12-dimethylbenz (a) anthracene (DMBA) induced skin carcinogenesis in Swiss albino mice. J Environ Biol. 2012;33:255-60.

24. Parmar J, Sharma P, Verma P, Sharma P, Goyal PK. Modulation of DMBA-induced biochemical and histopathological changes by Syzygium cumini seed extract during skin carcinogenesis. Int J Cur Biomed Phar Res. 2011;1(2):24-30.

25. Chaudhary G, Parmar J, Verma P, Goyal PK. Inhibition of dimethylebenz (a) anthracene (DMBA)/croton oil induced skin tumorigenesis in Swiss albino mice by Aloe vera treatment. Int J Biol Med Res. 2011;2(3):671-8.

26. Gabhe SY, Tatke PA, Khan TA. Evaluation of the immunomodulatory activity of the methanol extract of Ficus benghalensis roots in rats. Indian J Pharmacol. 2006;38(4):271-5. doi: 10.4103/0253-7613.27024.

27. Boubaker J, Chaabane F, Bedoui A, Aloui R, Ahmed BB, Ghedira K, et al. Antitumoral potency of methanolic extract from Nitraria retusa leaves via its immunomodulatory effect. Cancer Cell Int. 2015;15(82):1-9. doi: 10.1186/ s12935-015-0232-y.

28. Choi JH, Jo SG, Jung SK, Park WT, Kim KY, Park YW, et al. Immunomodulatory effects of ethanol extract of germinated ice plant (Mesembryanthemum crystallinum). Lab Anim Res. 2017;33(1):32-39. doi: 10.5625/lar.2017.33.1.32. 